\title{
SỬ DỤNG DUNG DỊCH LIỆT TIM MÁU ẤM ĐỂ BẢO VỆ CƠ TIM TRONG PHẪU THUẬT TIM NGƯỜI LỚN
}

Đoàn Đức Hoằng*, Truơng Tuấn Anh*, Lê Nhật Anh*, Phan Tái Nhân*, Đặng Quốc Kha*

\section{TÓM TÁ́T}

Chúng tôi nghiên cứu hồi cứu, trong 14 năm $(2004$ - 2018), trên những bệnh nhân phẫu thuật tim $(n=6720)$ được sử dụng dung dịch liệt tim máu ấm để bảo vệ cơ tim. Chúng tôi đánh giá mức độ tổn thương cơ tim dựa vào các biến số ghi nhận vào các thời điểm từ trước mổ $\left(\mathrm{T}_{0}\right), 2$ giờ sau kết thúc phẫu thuật $\left(\mathrm{T}_{2}\right), 8$ giờ sau mổ $\left(\mathrm{T}_{8}\right)$ và 24 giờ sau mổ $\left(\mathrm{T}_{\text {off }}\right)$ về nồng độ Troponin $\mathrm{T}$, tỷ lệ khử rung tim tự nhiên sau mở cặp động mạch chủ, sử dụng hỗ trợ tuần hoàn bằng kỹ thuật bơm bóng đối xung trong động mạch chủ, sử dụng thuốc trợ tim inotrope, và chức năng tim sau mổ như cung lượng tim, phân suất tống máu thất trái cũng như các kết quả hồi sức về thời gian thở máy, thời gian điều trị tại phòng hồi sức. Tỷ lệ đáng kể những bệnh nhân có nguy cơ cao trước mổ như suy tim nặng NYHA.III-IV (81,3\%), tăng áp phổi với $\mathrm{PAPS} \geq 55 \mathrm{mmHg}(27,7 \%)$ hoặc phải trải qua phẫu thuật phức tạp $(39,3 \%)$ như phẫu thuật đa van tim, hoặc phối hợp phẫu thuật van tim với bắc cầu chủ vành... Tuy nhiên, có cải thiện đáng kể chức năng tim sau mổ như phân suất tống máu thất trái $(\mathrm{p}<0,05)$, cung lượng tim $(\mathrm{p}<0,05)$ và cải thiện thời gian thở máy $(22,56 \pm 30,04$ giờ $)$, thời gian điều trị trị phòng hồi sức (51,16 $\pm 35,13$ giờ).

\section{SUMMARY}

THE APPLICATION OF WARM BLOOD

CARDIOPLEGIA FOR MYOCARDIAL PROTECTION DURING CARDIAC SURGERY IN ADULT

We retrospectively analyzed, over 14 years (2004-2018), early results of cardiac surgical patients $(\mathrm{n}=6720)$ using warm blood cardioplegia for myocardial protection. We access the myocardial cell injury base on research variables collected before surgery, $2 \mathrm{~h}, 8 \mathrm{~h}$ and $24 \mathrm{~h}$ postoperatively of cardiac troponin $\mathrm{T}$ level, spontaneous defibrillation after removing aortic clamp, use of intra-aortic balloon counter pulsation (IABP), and use of inotropic support, and evaluated cardiac function such as cardiac output measurement, left ventricular ejection fraction as well as the clinical outcome such as ventilation time and ICU stay in these patients.

Results: Preoperative demographic and clinical variables with high risk factors were severe heart failure at NYHA.III-IV (81,3\%), severe pulmonary artery hypertension $(27,7 \%)$ and patients undergoing complicated surgery $(39,3 \%)$ such as multi-valvular surgery or combined valvular and coronary surgery... and long duration in aortic clamp (40,5\%) or in cardiopulmonary bypass $(40,2 \%)$. However, postoperatively, there was a significantly goof progress in cardiac function such as left ventricular ejection fraction $(\mathrm{p}<0,05)$, cardiac output $(\mathrm{p}<0,05)$ and in clinical outcome such as reduced ventilation time $(22,56 \pm 30,04$ hours $)$ as well as ICU stay $(51,16 \pm 35,13$ hours).

Keywords: Cardiac surgery, cardiopulmonary bypass; myocardial protection; Troponin T; Ischemia-reperfusion injury; left ventricular ejection fraction.

\section{I. ĐặT VẤN ĐỀ}

Sử dụng tuần hoàn ngoài cơ thể, làm liệt

\footnotetext{
* Trung tâm Tim mạch, Bệnh viện Trung uoong Huế Người chịu trách nhiệm khoa hoc: TS. Đoàn Đúc Hoằng Ngày nhận bài: 01/05/2018 - Ngày Cho Phép Đăng: 20/05/2018

Phản Biện Khoa học: GS.TS. Bùi Đức Phú PGS.TS. Đặng Ngọc Hùng
} 
tim, và tái tưới máu cơ tim sau cặp động mạch chủ là những nguyên nhân gây ra phản ứng viêm hệ thống và gây tổn thương cơ tim do thiếu máu tái tưới máu, và điều này làm tăng đáng kể các biến chứng sau mổ [1]. Nếu Sử dụng dung dịch liệt tim để làm ngừng hoạt động của tim vào thì tâm trương bằng cách bơm một dung dịch giàu kali vào trong động mạch vành, qua đó giúp làm giảm tiêu thụ oxy cơ tim đến $90 \%$, nếu như dung dịch này được sử dụng ở môi trường có nhiệt độ sinh lý [2].

Vào thập niên 1990s, nhiều nghiên cứu đã chứng tỏ việc sử dụng dung dịch liệt tim máu ấm $\left(>28^{0} \mathrm{C}\right)$ giúp cải thiện chức năng tim và giảm phóng thích các men tim sau phẫu thuật. Sử dụng dung dịch liệt tim máu ở nhiệt độ sinh lý giúp bảo vệ cơ tim trong quá trình phẫu thuật và làm giảm các biến chứng sau mổ. Khác với dung dịch tinh thể, khi làm liệt tim thì máu giúp vận chuyển lượng oxy lớn hơn đến cơ tim và làm giảm quá trình pha loãng do đó tạo nên môi trường gần như sinh lý. Dung dịch liệt tim máu ưu điểm hơn dung dịch tinh thể giúp ức chế các protein gây quá trình tự tiêu tế bào do tổn thương thiếu máu - tái tưới máu [3].

Cho đến nay vẫn chưa có sự đồng thuận về sử dụng một phương pháp liệt tim tối ưu nhằm giảm thiểu các tổn thương cơ tim trong quá trình phẫu thuật. Có nhiều chến lược để cố gắng giảm thiểu sự tổn thương cơ tim do thiếu máu - tái tưới máu, bao gồm sử dụng hệ thống tuần hoàn ngoài cơ thể ít xâm nhập, chuẩn bị các điều kiện giúp tim "đề kháng" tốt hơn với các tổn thương thiếu máu và tối ưu phương pháp liệt tim chính là mục tiêu của nghiên cứu này.

\section{II. ĐỐI TƯợNG VÀ PHƯƠNG PHÁP NGHIÊN CÚU}

Nghiên cứu hồi cứu trên 6720 bệnh nhân phẫu thuật tim người lớn tại Trung tâm tim mạch. Bệnh viện Trung ương Huế trong 14 năm (2004-2018).

\section{1. Đánh giá trước mổ $\left(\mathrm{T}_{0}\right)$}

-Thăm khám bệnh lý gồm các triệu chứng suy tim, triệu chứng thiếu máu cơ tim, các yếu tố nguy cơ đối với bệnh nhân phẫu thuật tim.

-Xét nghiệm tiền phẫu thường qui, trắc nghiệm gắng sức và men tim troponin $\mathrm{T}$ vào hôm trước phẫu thuật.

-Siêu âm tim và chụp động mạch vành chẩn đoán bệnh lý van tim, bệnh động mạch vành, phát hiện các vận động các thành tim, đo phân suất tống máu và bệnh tim khác.

-Loại hình phẫu thuật tim, can thiệp đa van, phối hợp can thiệp van tim và bắc cầu chủ vành, phẫu thuật tim cấp cứu và phẫu thuật lần 2 trở lên...

\section{2. Đánh giá theo dõi trong mổ:}

-Điện tâm đồ 12 chuyển đạo liên tục.

-Nhiệt độ cơ thể.

-Bảo hòa oxy máu ngoại vi, khí máu động mạch, nồng độ hemoglobin.

-Các thông số huyết động xâm nhập như huyết áp động mạch, áp, áp lực tĩnh mạch trung tâm, áp lực động mạch phổi, đo cung lượng tim, và siêu âm tim qua thực quản.

- Đánh giá như cầu sử dụng thuốc hỗ trợ co bóp tim (loại thuốc, liều lượng, phối hợp thuốc) hoặc sử dụng hỗ trợ tuần hoàn bằng bơm bóng đối xung trong độn mạch chủ.

- Thời gian tuần hoàn ngoài cơ thể (phút).

-Thời gian cặp động mạch chủ (phút).

- Ghi nhận và đánh giá các tổn thương cấu trúc tim được sữa chữa (số cầu nối, van tim).

2.2.1. Đánh giá sau mổ: thời điểm $2 \mathrm{~h}\left(\mathrm{~T}_{2}\right)$, $8 \mathrm{~h}\left(\mathrm{~T}_{8}\right)$ và $24 \mathrm{~h}\left(\mathrm{~T}_{24}\right)$ sau khi về phòng hồi sức

-Định lượng nồng độ troponin $\mathrm{T}$ vào các thời điểm trước và sau mổ như trên (nồng độ troponin $\mathrm{T}$ tăng hơn gấp $2-10$ lần với trước mổ). 
- Đánh giá các thông số huyết động nêu trên

-Nhu cầu sử dụng inotrope (liều lượng, phối hợp thuốc, thời gian sử dụng).

-Đánh giá biến chứng nhồi máu cơ tim sau mổ.

-Đánh giá biến chứng suy thận sau mổ (creatinine máu $>2 \mathrm{mg} / \mathrm{dL}$ hoặc tăng hơn gấp đôi so với trước mổ).

-Siêu âm tim sau mổ đánh giá các rối loạn vận động vùng, tràn dịch màng tim hoặc phát

\section{KÊTT QUẢ NGHIÊN CÚU}

\subsection{Số liệu trước mổ}

* Đặc điểm các yếu tố nguy cơ trong phẫu thuật

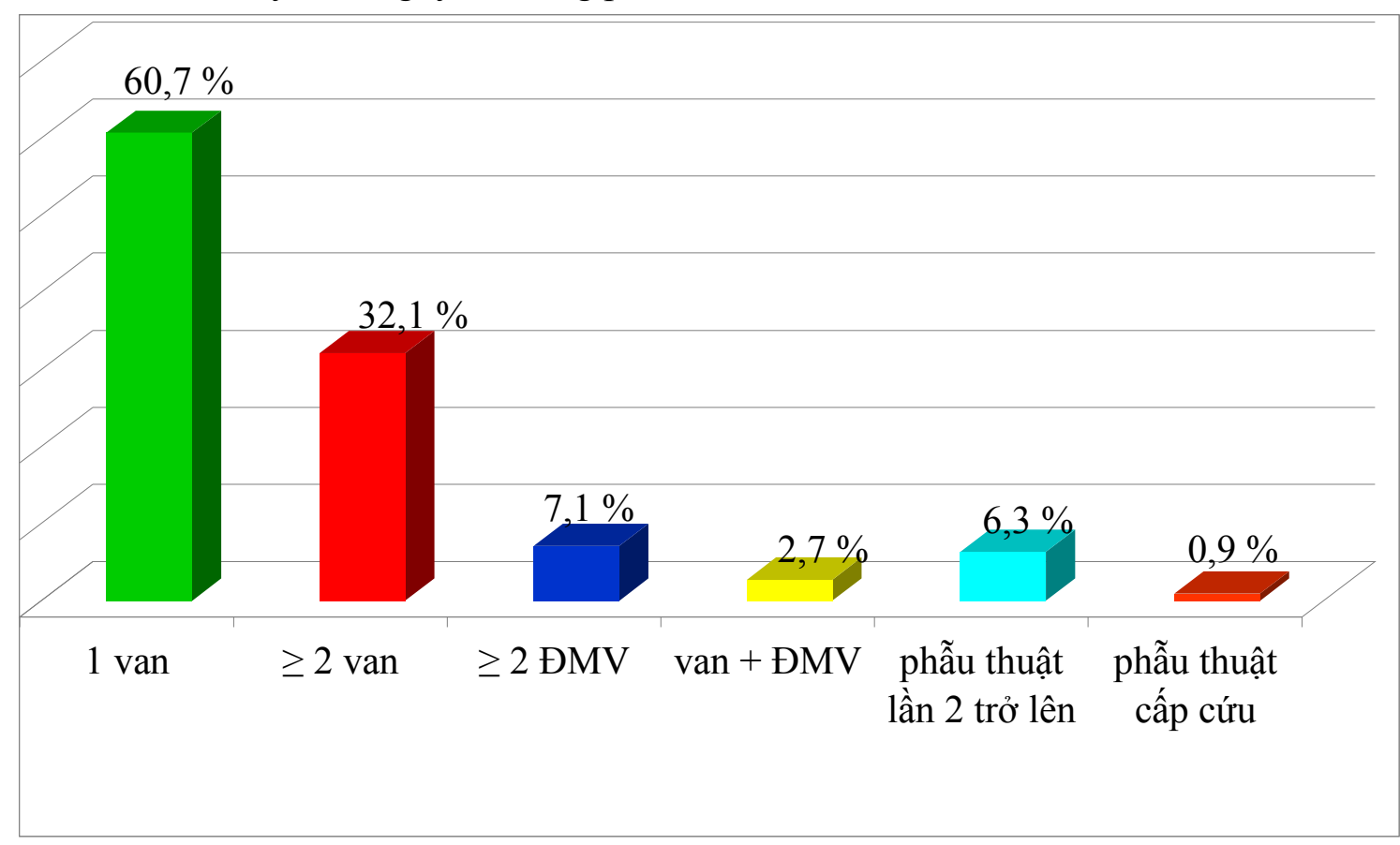

Biểu đồ 3.1. Đặc điểm phân bố các loại hình phẫu thuật tim

Nhận xét: Loại hình phẫu thuật đồng thời từ 02 van tim trở lên chiếm tỷ lệ nhiều nhất $(32,1 \%)$; Đa số là loại hình phẫu thuật tim có kế hoạch, phẫu thuật cấp cứu rất ít $(0,9 \%)$.

* Đặc điểm các yếu tố nguy cơ trước phẫu thuật

Bảng 3.1. Đặc điểm các yếu tố nguy cơ trước phẫu thuật

\begin{tabular}{|l|c|c|}
\hline \multicolumn{1}{|c|}{ Yếu tố nguy cơ trước phẫu thuật } & n & $\mathbf{\%}$ \\
\hline Suy tim trước phẫu thuật (NYHA.III-IV) & 5460 & 81,3 \\
\hline Phân suất tống máu giảm EF $<50 \%$ & 2160 & 32,1 \\
\hline Tăng áp phồi PAPS $\geq 55 \mathrm{mmHg}$ & 1860 & 27,7 \\
\hline Nhồi máu cơ tim mới & 240 & 3,6 \\
\hline Tuối $\geq 60$ (năm) & 960 & 14,3 \\
\hline
\end{tabular}


Nhận xét: đa số bệnh nhân có NYHA.III-IV và có khoảng $1 / 3$ số bệnh nhân có biểu hiện giảm phân suất tống máu thất trái trước phẫu thuật.

\subsection{Số liệu trong mổ}

* Đặc điểm thời gian tuần hoàn ngoài cơ thể, thời gian cặp động mạch chủ

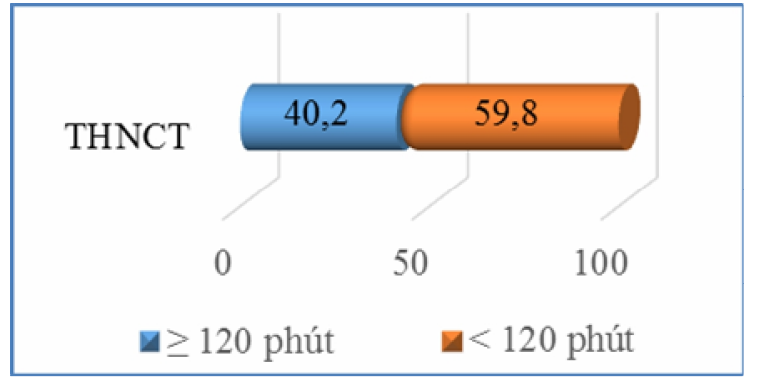

Biểu đồ 3.2. Thò̀i gian THNCT

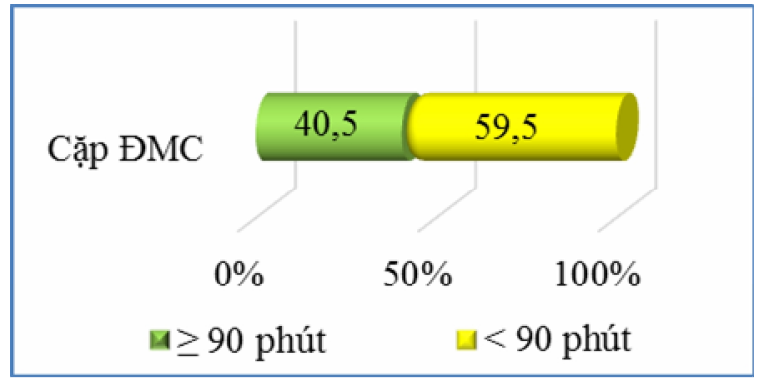

Biểu đồ 3.3. Thời gian cặp ĐMC

Nhận xét: Thời gian tuần hoàn ngoài cơ thể kéo dài $\geq 120$ phút, và thời gian cặp động mạch chủ $\geq$ 90 phút chiếm tỷ lệ đáng kể $(40,2 \%$ và $40,5 \%)$.

* Tỷ lệ khử rung tim tự nhiên sau mở cặp động mạch chủ là 92\%.

3.3. Số liệu tại phòng hồi sức sau mổ

* Nồng độ hemoglobin

Bảng 3.2. Kết quả đo lường nồng độ hemoglobin

\begin{tabular}{|c|c|c|c|}
\hline $\mathbf{H b}(\mathrm{g} / \mathrm{dL})$ & $\mathbf{T}_{\mathbf{0}}$ & $\mathbf{T}_{\mathbf{2}}$ & $\mathbf{T}_{\mathbf{8}}$ \\
\hline $\mathrm{Hb}-\mathrm{min}$ & 9,0 & 8,3 & 7,3 \\
\hline $\mathrm{Hb}-\mathrm{max}$ & 17,0 & 15,3 & 14,6 \\
\hline $\mathrm{Hb} \geq 8 \mathrm{~g} / \mathrm{dL}$ & $6720(100 \%)$ & $6720(100 \%)$ & $6600(98,2 \%)$ \\
\hline $\mathrm{Hb}<8 \mathrm{~g} / \mathrm{dL}$ & $0(0 \%)$ & $0(0 \%)$ & $120(1,8 \%)$ \\
\hline $\mathrm{X} \pm \mathrm{SD}$ & $13,14 \pm 1,62$ & $11,17 \pm 1,44$ & $10,41 \pm 1,24$ \\
\hline $\mathrm{p}$ & $\mathrm{p}_{\mathrm{T} 0 \times \mathrm{T} 2}<0,05$ & $\mathrm{p}_{\mathrm{T} 0 \times \mathrm{xT}}<0,05$ & $\mathrm{p}_{\mathrm{T} 2 \times \mathrm{T} 8}<0,05$ \\
\hline
\end{tabular}

Nồng độ $\mathrm{Hb}$ giảm dần ở các thời điểm sau phẫu thuật trong giới hạn cho phép $(\geq 8 \mathrm{~g} / \mathrm{dL})$ và sự khác biệt này có ý nghĩa thống kê $(\mathrm{p}<0,05)$.

* Chỉ số tim (CI)

\begin{tabular}{|c|c|c|c|c|}
\hline CI (lít/phút/m²) & $\mathbf{T}_{\mathbf{0}}$ & $\mathbf{T}_{2}$ & $\mathbf{T}_{8}$ & $\mathbf{T}_{\text {off }}$ \\
\hline $\mathrm{CI}<2,2$ & $6000(89,3 \%)$ & $780(11,6 \%)$ & $900(13,4 \%)$ & $660(9,8 \%)$ \\
\hline $\mathrm{CI}=2,2-2,5$ & $540(8,0 \%)$ & $600(8,9 \%)$ & $1140(17,0 \%)$ & $1080(16,1 \%)$ \\
\hline $\mathrm{CI}>2,5$ & $180(2,7 \%)$ & $5340(79,5 \%)$ & $4680(69,6 \%)$ & $4980(74,1 \%)$ \\
\hline CI-TB & $1,67 \pm 0,43$ & $3,23 \pm 0,93$ & $2,90 \pm 0,77$ & $2,99 \pm 0,70$ \\
\hline $\mathrm{p}$ & $\mathrm{p}_{\mathrm{T} 0 \mathrm{xT} 2}<0,05$ & $\mathrm{p}_{\text {T0xT8 }}<0,05$ & $\mathrm{p}_{\text {T0xToff }}<0,05$ & $\mathrm{p}_{\text {T8xToff }}>0,05$ \\
\hline
\end{tabular}

Nhận xét: có nhiều bệnh nhân suy tim nặng trước phẫu thuật có $\mathrm{CI}<2,2$ lít/phút $/ \mathrm{m}^{2}$, tỷ lệ này giảm sau mổ và thấp nhất ở thời điểm $\mathrm{T}_{24}$. Tỷ lệ giảm bệnh nhân có chỉ số tim giảm nhưng vẫn trong giới hạn cho phép $\left(2,2 \leq \mathrm{CI} \leq 2,5\right.$ lít/phút $\left./ \mathrm{m}^{2}\right)$ ở thời điểm sau phẫu thuật $\left(\mathrm{T}_{2}, \mathrm{~T}_{8}, \mathrm{~T}_{24}\right)$ chiếm tỷ lệ thấp. Hầu hết bệnh nhân sau phẫu thuật cải thiện chỉ số tim $\left(\mathrm{CI} \geq 2,5\right.$ lít/phút $\left./ \mathrm{m}^{2}\right)$. Giá trị CI-TB tăng sau phẫu thuật $(\mathrm{p}<0,05)$, và giá trị này cao nhất thời điểm $\mathrm{T}_{2}$.

* Phân suất tống máu thất trái $(\mathrm{EF})$ 
Bảng 3.4. Kết quả đo lường giá trị phân suất tống máu thất trái

\begin{tabular}{|c|c|c|c|c|}
\hline EF (\%) & $\mathbf{T}_{\mathbf{0}}$ & $\mathbf{T}_{\mathbf{2}}$ & $\mathbf{T}_{\mathbf{8}}$ & $\mathbf{T}_{\text {off }}$ \\
\hline EF-min & 30 & 25 & 27 & 37 \\
\hline EF $\geq 50 \%$ & $4560(67,9 \%)$ & $5040(75,0 \%)$ & $5400(80,4 \%)$ & $4560(67,9 \%)$ \\
\hline EF-TB & $52,90 \pm 8,33$ & $54,51 \pm 8,91$ & $55,22 \pm 8,82$ & $56,50 \pm 7,86$ \\
\hline$P$ & $\mathrm{p}_{(\mathrm{T} 0) \mathrm{x}(\mathrm{T} 2)}<0,05$ & $\mathrm{p}_{(\mathrm{T} 0) \mathrm{x}(\mathrm{T} 8)}<0,05$ & $\mathrm{p}_{(\mathrm{T} 0) \mathrm{x}(\mathrm{T} 24)}<0,05$ & $\mathrm{p}_{(\mathrm{T} 8) \mathrm{x}(\mathrm{T} 24)}<0,05$ \\
\hline
\end{tabular}

Nhận xét: Tỉ lệ bệnh nhân có giá trị $\mathrm{EF} \geq 50 \%$ tăng đáng kể sau phẫu thuật; Biến thiên giá trị EF-TB tăng sau phẫu thuật, và sự khác biệt này là có ý nghĩa thống kê $(\mathrm{p}<0,05)$.

* Nồng độ troponin-T huyết tương

Bảng 3.5. Kết quả xét nghiệm nồng độ troponin-T huyết tương

\begin{tabular}{|c|c|c|c|}
\hline $\begin{array}{ll}\text { Thời điểm } & \text { Troponin-T } \\
\end{array}$ & $T_{0}(n=6420)$ & $T_{8}(n=6660)$ & $\mathbf{P}$ \\
\hline Troponin-T-TB (ng/mL) & $0,53 \pm 0,166$ & $0,711 \pm 0,462$ & $<0,05$ \\
\hline Troponin- $\mathrm{T}<2$ lần & $6000(93,5 \%)$ & $240(3,6 \%)$ & $<0,05$ \\
\hline Troponin-T tăng từ $2-<10$ lần & $360(5,6 \%)$ & $5160(77,5 \%)$ & $<0,05$ \\
\hline Troponin- $T$ tăng gấp $\geq 10$ lần & $60(0,9 \%)$ & $1260(18,9 \%)$ & $<0,05$ \\
\hline
\end{tabular}

Nhận xét: giá trị troponin-T-TB tăng sau mổ $(\mathrm{p}<0,05)$; phần lớn có nồng độ troponin-T tăng từ 2-10 lần ở $\mathrm{T}_{8}$ giờ sau mổ; một số bệnh nhân có troponin- $\mathrm{T}$ tăng $\geq 10$ lần ở thời điểm $\mathrm{T}_{8}$.

* Nhu cầu sử dụng thuốc tăng co bóp tim sau mổ

Bảng 3.6. Kết quả điều trị thuốc trợ tim

\begin{tabular}{|c|c|c|c|c|c|c|}
\hline \multicolumn{3}{|c|}{ Loại thuốc trọ tim TM } & $\mathbf{n}$ & Min & Max & $\mathbf{X} \pm \mathbf{S D}$ \\
\hline \multirow{2}{*}{$\begin{array}{c}\text { Dobutamin } \\
\text { (mcg/kg/phút) }\end{array}$} & $\leq 10$ & 5400 & \multirow{2}{*}{$5400(80,4 \%)$} & \multirow{2}{*}{1,46} & \multirow{2}{*}{8,70} & \multirow{2}{*}{$5,70 \pm 1,54$} \\
\hline & $>10$ & 0 & & & & \\
\hline \multirow{2}{*}{$\begin{array}{c}\text { Adrenalin } \\
\text { (mcg/kg/phút) }\end{array}$} & $\leq 0,2$ & 1620 & \multirow{2}{*}{$1920(28,6 \%)$} & \multirow{2}{*}{0,03} & \multirow{2}{*}{0,25} & \multirow{2}{*}{$0,13 \pm 0,05$} \\
\hline & $>0,2$ & 300 & & & & \\
\hline \multirow{2}{*}{$\begin{array}{l}\text { Noradrenalin } \\
\text { (mcg/kg/phút) }\end{array}$} & $\leq 0,2$ & 1320 & \multirow{2}{*}{$1860(27,7 \%)$} & \multirow{2}{*}{0,05} & \multirow{2}{*}{0,49} & \multirow{2}{*}{$0,17 \pm 0,10$} \\
\hline & $>0,2$ & 540 & & & & \\
\hline
\end{tabular}

Nhận xét: Phần lớn bệnh nhân cần điều trị dobutamin sau mổ, và tỷ lệ đáng kể cần điều trị bởi adrenalin, hoặc noradrenalin; Rất ít bệnh nhân cần phải điều trị thuốc trợ tim liều cao

Bảng 3.7. Kết quả phối hợp các thuốc trọ̣ tim

\begin{tabular}{|c|c|c|}
\hline Phối hợp các thuốc trợ tim tĩnh mạch & n & Tỷ lệ \% \\
\hline Không sử dụng thuốc trợ tim tĩnh mạch & 720 & 10,7 \\
\hline Sử dụng 1 loại thuốc trợ tim tĩnh mạch & 3540 & 52,7 \\
\hline Phối hợp 2 loại thuốc trợ tim tĩnh mạch & 1740 & 25,9 \\
\hline Phối hợp 3 loại thuốc trợ tim tĩnh mạch & 720 & 10,7 \\
\hline Tổng & 6720 & 100,0 \\
\hline
\end{tabular}

Nhận xét: phần lớn bệnh nhân chỉ cần điều trị bởi 1 loại thuốc thuốc trợ tim đường tĩnh mạch, hỗ trợ bởi 2 loại thuốc trợ tim đường tĩnh mạch chiếm tỷ lệ ít hơn, và rất ít bệnh nhân sử dụng phối hợp cả 3 loại thuốc trợ tim đường tĩnh mạch.

* Liệu pháp hố trọ tuần hoàn co học bằng bơm bóng đối xung trong động mạch chủ 
Bảng 3.8. Kết quả của liệu pháp điều trị hỗ trợ tuần hoàn cơ học

\begin{tabular}{|l|c|c|c|}
\hline \multicolumn{1}{|c|}{ Hỗ trọ̣ bóng đối xung trong động mạch chủ } & $\mathbf{n}$ & Tỷ lệ \% & \multirow{2}{*}{ P } \\
\hline Không hỗ trợ bóng đối xung trong ĐMC & 6420 & 95,5 & \multirow{2}{*}{$<0,05$} \\
\cline { 1 - 3 } Hỗ trợ bóng đối xung trong ĐMC từ 3 - 7 ngày & 240 & 3,6 & \\
\hline Hỗ trợ bóng đối xung trong ĐMC > 7 ngày & 60 & 0,9 & \\
\hline \multicolumn{1}{|c|}{ Tồng } & 6720 & 100,0 & \\
\hline
\end{tabular}

Nhận xét: một số ít bệnh nhân cần hỗ trợ tuần hoàn cơ học $(\mathrm{p}<0,05)$, và thường hồi phục sớm sau một thời gian hỗ trợ ngắn (3 - 7 ngày).

3.4. Kết quả điều trị tại phòng hồi sức

* Thời gian thở máy

Bảng 3.9. Kết quả thời gian thở máy

\begin{tabular}{|l|c|c|}
\hline \multicolumn{1}{|c|}{ Thò̀i gian thở máy } & Chung & P \\
\hline Tthời gian thở máy trung bình $(\mathrm{n}=6720)$ & $22,56 \pm 30,04$ & \\
\hline Thời gian thở máy $\leq 48$ giờ & $6300(93,8 \%)$ & \multirow{2}{*}{$<0,05$} \\
\hline Thời gian thở máy > 48 giờ & $420(6,2 \%)$ & \\
\hline
\end{tabular}

Nhận xét: Đa số bệnh nhân có thời gian thở máy $\leq 48$ giờ (ngắn nhất 5 giờ); Một số ít bệnh nhân có thời gian thở máy kéo dài (dài nhất 192 giờ).

Bảng 3.10. Kết quả thời gian điều trị tại phòng hồi sức

\begin{tabular}{|l|c|c|}
\hline \multicolumn{1}{|c|}{ Thời gian hồi sức } & Chung & P \\
\hline Thời gian trung bình điều trị tại ICU $(\mathrm{n}=6720)$ & $51,16 \pm 35,13$ & \\
\hline Thời gian điều trị tại ICU $\leq 72$ giờ & $6240(92,9 \%)$ & \multirow{2}{*}{$<0,05$} \\
\hline Thời gian điều trị tại ICU > 72 giờ & $480(7,1 \%)$ & \\
\hline
\end{tabular}

Nhận xét: Đa số bệnh nhân có thời gian hồi sức $\leq 72$ giờ (ngắn nhất 18 giờ), và một số ít bệnh nhân có thời gian hồi sức kéo dài $>72$ giờ (dài nhất 240 giờ).

\section{BÀN LUẬN}

Mục đích của bảo vệ cơ tim trong quá trình phẫu thuật nhằm bảo tồn chức năng tim trong điều kiện tim không được cấp máu và ngừng hoạt động cũng như phẫu trường sạch không máu. Trước đây, người ta thường hạ thân nhiệt nhằm làm giảm nhu cầu chuyển hóa cơ tim [4]. Kỹ thuật này làm cho hạ nhiệt độ cơ tim, thiếu máu cơ tim và làm chậm phục hồi hoạt động chuyển hóa cũng như chậm phục hồi chức năng của cơ tim sau mổ [5].

Tuy nhiên, việc làm ngừng hoạt động điện cơ tim giúp làm giảm tiêu thụ oxy đến $90 \%$, trong khi nếu làm giảm nhiệt độ cơ tim cho đến $11^{\circ} \mathrm{C}$ cũng chỉ làm giảm tiêu thu oxy cơ tim một tỷ lệ rất thấp [6]. Đây chính là cơ sở mà nhiều nghiên cứu đã đưa vào sử dụng dung dịch liệt tim máu ấm trong quá trình phẫu thuật tim từ năm since 1980 [7]. Kỹ thuật này đã giúp cải thiện sự hồi phục hoạt động chuyển hóa và chức năng cơ tim và tạo được niềm tin ở nhiều phẫu thuật viên tim mạch từ những năm đầu của thập kỷ 1990s [8]. Thuận lợi nổi bật của kỹ thuật này là chỉ làm pha loãng máu rất ít và tiết kiệm vì đây là kỹ thuật đơn giản không đòi hỏi những thiết bị đắt tiền như máy trao đổi nhiệt [9].

Sử dụng dung dịch liệt tim máu giúp làm giảm hoạt động chuyển hóa kỵ khí của cơ tim trong thời gian cặp động mạch chủ và vì vậy giảm sản xuất lactate [10]. Kỹ thuật bơm ngắt quãng dung dịch liệt tim máu ấm giúp bảo tồn chức năng tâm thu, và cải thiện đáp ứng chronotropic ở cả thì tâm thu và thì tâm trương [11]. 
Tuy nhiên, sau hơn 30 năm ứng dụng, cho đến nay vẫn còn nhiều nghi vấn rằng dung dịch liệt tim máu ấm có là ưu việt hơn hay không [4]. Trong nghiên cứu này với số lượng bệnh nhân lớn $(n=6720)$ trong 14 năm (2004-2018) đã cho kết quả rất khả quan. Chúng tôi sử dụng mức tăng phóng thích men tim troponin $\mathrm{T}$ để chỉ điểm tình trạng tổn thương cơ tim và cho thấy rằng chỉ điểm này đáng tin cậy hơn so với những dấu chứng thay đổi ECG sau mổ vì những biến đổi này thường là không rõ nét ở pha khởi đầu của các rối loạn chức năng cơ tim, không phổ biến ở giai đoạn sớm sau mổ.

Trong nghiên của chúng tôi, các yếu tố nguy cơ phẫu thuật tim nổi bật như tỷ lệ khá cao bệnh nhân suy tim trước mổ NYHA III/IV $(81.3 \%)$, tỷ lệ tăng áp phổi nặng cũng đáng kể (27.7\%). Loại hình phẫu thuật tim phức tạp như can thiệp đa van tim chiếm đa số (34.7\%) và thường có kéo dài thời gian tuần hoàn ngoài cơ thể trên 120 phút và thời gian cặp động mạch chủ trên 90 phút chiếm tỷ lệ đáng kể (41.3\% và 40.5\%).

Chức năng thất trái giảm được xem là một chỉ điểm độc lập tiên lượng xảy ra biến chứng sau mổ. Trong nghiên cứu này số lượng bệnh nhân có phân suất tống máu giảm $(\mathrm{EF}<50 \%)$ chiếm tỷ lệ đáng kể $(32,1 \%)$, trong đó, có những bệnh nhân giảm chức năng tim nặng $(30 \% ; 25 \% ; 27 \%$ và $37 \%$ ở các thời điểm $\mathrm{T}_{0} ; \mathrm{T}_{2} ; \mathrm{T}_{8} ;$ và $\left.\mathrm{T}_{24}\right)$. Giá trị EF-TB biến thiên tăng $(52,90 \pm 8,33$ tăng lên $54,51 \pm 8,91$; đến $55,22 \pm 8,82$; và $56,50 \pm 7,86$; p < 0,05 ; bảng 3.16 .) cho thấy kết quả là khả quan khi sử dụng dung dịch liệt tim máu ấm.

Giá trị cung lượng tim trung bình trước phẫu thuật thấp $\left(\mathrm{CO}-\mathrm{TB}_{\mathrm{T} 0}=2,53 \pm 0,70\right.$ lít/phút; thấp nhất: 1,35 lít/phút). Biến thiên tăng $\mathrm{CO}$ sau phẫu thuật $(2,53 \pm 0,70$ tăng lên $4,59 \pm 1,14$ lít/phút; $\mathrm{p}<0,05)$. Giá trị $\mathrm{CO}-\mathrm{TB}$ đo ở thời điểm $\mathrm{T}_{2}$ là cao nhất $\left(\mathrm{CO}-\mathrm{TB}_{\mathrm{T} 2}=4,86 \pm 1,35\right.$ lít/phút $)$ nhờ những điều kiện thuận lợi như chức năng tim cải thiện do các thương tổn tim đã được phẫu thuật sửa chữa; hơn nữa, ngay sau phẫu thuật bệnh nhân thường được hỗ trợ các thuốc làm tăng co bóp tim; tác động phẫu thuật chưa ảnh hưởng nhiều trong điều kiện bệnh nhân thở máy được an thần, giảm đau tốt, tác dụng của thuốc mê còn lại làm giảm hoạt động chuyển hóa cơ thể. Giá trị $\mathrm{CO}-\mathrm{TB}$ đo vào thời điểm sau phẫu thuật cải thiện $\left(\mathrm{CO}-\mathrm{TB}_{\mathrm{T} 8}=4,41 \pm 1,22\right.$ so với $\mathrm{CO}-\mathrm{TB}_{\mathrm{Toff}}=4,59$ $\pm 1,14$ lít/phút ; $\mathrm{p}<0,05$; bảng 3.10.). Chúng tôi ghi nhận giá trị $\mathrm{CO}-\mathrm{TB}$ đo ở các thời điểm $\mathrm{T}_{8}$ và $\mathrm{T}_{\text {off }}$ có kết quả thấp hơn so với thời điểm $\mathrm{T}_{2}$ với lý do vào các thời điểm này thường bệnh nhân đã được cai các thuốc trợ tim; đồng thời tác động phẫu thuật ảnh hưởng nhiều hơn trong điều kiện đã cai thở máy, hết tác dụng các thuốc gây mê, an thần, đau sau phẫu thuật làm tăng hoạt động chuyển hóa cơ thể. Tuy vậy, thời điểm $\mathrm{T}_{\text {off }}$ là thời điểm quyết định ngừng nghiên cứu.

Trong nghiên cứu này tỷ lệ đáng kể bệnh nhân phải cần kéo dài thời gian tuần hoàn ngoài cơ thể kéo dài $\geq 120$ phút, và thời gian cặp động mạch chủ $\geq 90$ phút $(40,2 \%$ và $40,5 \%)$. Tuy nhiên, các dấu hiệu chỉ điểm cơ tim phục hồi tốt sau mở cặp động mạch chủ gồm tỷ lệ khử rung tim tự nhiên cao (92\%) trong khi tỷ lệ này là thấp nếu sử dụng dung dịch liệt tim tinh thể như trong nghiên cứu của I. Jacquet và cộng sự $(83.6 \%)$ [12]. Mức độ tổn thương cơ tim do thiếu máu là trong giới hạn cho phép $(81,1 \%$ có tăng troponin $\mathrm{T}<10$ lần so với giá trị cơ bản). Sử dụng thuốc hỗ trợ co bóp tim là đáng kể tuy nhiên rất ít khi sử dụng liều cao $(<5 \%$ số bệnh nhân có sử dụng adrenaline với liều $>0,2$ $\mathrm{mcg} / \mathrm{kg} / \mathrm{phút}$ ) và tỷ lệ thấp cần phối hợp 3 thứ thuốc inotrope $(10,7 \%)$. Các kết quả về thời gian thở máy cải thiện rút ngắn $(22,56 \pm 30,04$ giờ và chỉ $6,2 \%$ có thời gian thở máy $>48$ giờ) và thời gian điều trị tại ICU cải thiện rõ $(51,16$ $\pm 35,13$ giờ và chỉ $7,1 \%$ có thời gian thở máy $>48$ giờ) góp phần phản ánh kết quả của phương pháp bảo vệ cơ tim. 


\section{KẾT LUẬN}

Đây là một nghiên cứu trên số lượng bệnh nhân rất lớn $(n=6720)$ trong thời gian dài (14 năm) cho thấy giảm đáng kể mức độ giải phóng men tim và cải thiện chức năng tim sau mổ, cải thiện huyết động và kết quả hồi sức sau mổ ở những bệnh nhân phẫu thuật tim được bảo vệ cơ tim bằng dung dịch liệt tim máu ấm. Phương pháp bảo vệ cơ tim bằng dung dịch liệt tim máu ấm giúp cải thiện các chỉ điểm đánh giá chức năng tim qua đó đạt được các kết quả lâm sàng tốt hơn so với sử dụng dung dịch liệt tim tinh thể.

\section{TÀI LIỆU THAM KHẢO}

[1] Turer AT, Hill JA. Pathogenesis of myocardial ischemia-reperfusion injury and rationale for therapy. Am J Cardiol 2010;106(3):360e8.

[2] Buckberg GD, Brazier JR, Nelson RL, Goldstein SM, McConnell DH, Cooper N. Studies of the effects of hypothermia on regional myocardial blood flow and metabolism during cardiopulmonary bypass. I. The adequately perfused beating, fibrillating, and arrested heart. J Thorac Cardiovasc Surg 1977;73(1):87e94.

[3] Feng J, Bianchi C, Li J, Sellke FW. Improved profile of bad phosphorylation and caspase 3 activation after blood versus crystalloid cardioplegia. Ann Thorac Surg 2004;77:1384e9.

[4] Fan Y, Zhang A-M, Xiao Y-B, Weng Y-G, Hetzer R. Warm versus cold cardioplegia for heart surgery: a meta-analysis. Eur J Cardiothorac Surg 2010;37(4):912e9.

[5] Fremes SE, Weisel RD, Mickle DA, Ivanov J, Madonik MM, Seawright SJ, et al. Myocardial metabolism and ventricular function following cold potassium cardioplegia. J Thorac
Cardiovasc Surg 1985;89(4):531e46.

[6] Brown Jr IW, Smith WW, Emmons WO. An efficient blood heat exchanger for use with extracorporeal circulation. Surgery 1958;44(2):372e7. F.A. Mourad et al. / Journal of the Egyptian Society of Cardio-Thoracic Surgery 24 (2016) 215e222 221

[7] Calafiore AM, Teodori G, Mezzetti A, Bosco G, Verna AM, Di Giammarco G, et al. Intermittent antegrade warm blood cardioplegia. Ann Thorac Surg 1995;59(2):398e402.

[8] Fremes SE, Christakis GT, Weisel RD, Mickle DA, Madonik MM, Ivanov J, et al. A clinical trial of blood and crystalloid cardioplegia.

J Thorac Cardiovasc Surg 1984;88(5 Pt 1):726e41.

[9] Dar MI. Cold crystalloid versus warm blood cardioplegia for coronary artery bypass surgery. Ann Thorac Cardiovasc Surg 2005;11(6):382e5.

[10] Sirvinskas E, Nasvytis L, Raliene L, Vaskelyte J, Toleikis A, Trumbeckaite S. Myocardial protective effect of warm blood, tepid blood, and cold crystalloid cardioplegia in coronary artery bypass grafting surgery. Croat Med J 2005;46(6):879e88.

[11] Bouchart F. Myocardial revascularization in patients with severe ischemic left ventricular dysfunction. Long term follow-up in 141 patients. Eur J Cardio-Thoracic Surg 2001;20(6):1157e62.

[12] Jacquet LM, Noirhomme PH, Van Dyck MJ, El Khoury GA, Matta AJ, Goenen MJ, et al. Randomized trial of intermittent antegrade warm blood versus cold crystalloid cardioplegia. Ann Thorac Surg 1999;67(2):471e7. 